\title{
Olga Demydenko
}

$\mathrm{PhD}$, Associate Professor

National Technical University of Ukraine

"Igor Sikorsky Kyiv Polytechnic Institute"

Kyiv, Ukraine

ORCID 0000-0002-0643-5510

olga.demydenko80@gmail.com

\section{Liudmyla Vlasiuk}

Master student

National Technical University of Ukraine

"Igor Sikorsky Kyiv Polytechnic Institute"

Kyiv, Ukraine

Lyudmyla_98@ukr.net

\section{Olena Miroshnychenko}

Master student

National Technical University of Ukraine

"Igor Sikorsky Kyiv Polytechnic Institute"

Kyiv, Ukraine

elorianelena@gmail.com

\section{TERMINOLOGICAL ALLUSIVENESS AS A DISTINCTIVE FEATURE OF MODERN MEDIA DISCOURSE}

\begin{abstract}
It is stated that today's media is firmly entrenched in human society. The media discourse is a powerful tool of influencing the human mind. Being dynamic in nature, the language of the media responds most quickly to all the changes in public consciousness. It is in the language of the media that it is easy to notice the new trends in approaches to language learning. A special place is occupied by the terminological allusiveness that plays an important role in the study of language of the XXI century. This article is devoted to the investigation of such linguistic phenomenon as terminological allusiveness specifically in the media discourse. The authors begin the study with the general overview of the main features, functions and categories of the media discourse. In addition, they describe key peculiarities of the allusion and term phenomena. At the same time, special attention is paid to the unconventional combination of the allusive units with terms of the exact and natural sciences as an exclusive stylistic device of the media discourse. The research paper also presents the various approaches to classification of such linguistic phenomenon, which are supported by the multiple examples. The research encourages the idea of further investigation of terminological allusiveness. The results of this study can assist any linguist in adequate media discourse analysis.
\end{abstract}

Keywords: allusion; exact and natural sciences terminology; linguistic studies; media discourse; media text; terminological allusiveness.

\section{INTRODUCTION}

Media discourse has always been a subject of multiple investigations. Since its key aim is to exert major influence and convince the reader of the credibility and correctness of the given facts, its methods, strategies and tactics have sparked interest in the scientific circles. Particular interest has raised the question of various language means, the use of which allows media to reach its main goal.

However, media discourse just like any other phenomenon is subjected to diverse changes, among which the extensive use of allusions and terminology confluence occupies a central place. Many scientists have raised this issue in their works dedicated to linguistic studies. Among them we can distinguish the following names: Selivanova, Lavrynenko, Yarema, Vynogradov, Potapenko, Bilozerska, Lotte, Perri, Pfister, Lennon, Bell and many others well-known scholars. Nevertheless, the phenomenon of allusions and terminology confluence, known as "terminological allusiveness", still remains one of the most controversial issues in modern linguistics and causes heated debates in 
the scientific community.

The main purpose of the research discussed in the paper was to investigate the nature of the concept "terminological allusiveness" as a leading linguistic method of providing intertextual connections and exerting impact on the reader in modern media discourse.

\section{METHODS}

To achieve the goal of the research, we used the following methods of research: analysis and synthesis to give a detailed investigation of both phenomenon of allusion and term and peculiarities of their functioning in media discourse; induction and deduction to analyze the essence of notion of "terminological allusiveness", approaches to its typology as well as its functions in the text; "words and things" method and contextual method to explain the meaning of the allusive term and its realization in the context given; bibliographical method to adapt various scientific works; generalization method to sum up the key aspects of the notion "terminological allusiveness" on the basis of diverse linguistic research and method of continuous sample to collect appropriate examples.

\section{RESULTS AND DISCUSSION}

\subsection{Overview of the notion "media discourse", its typology, key features and characteristics}

Media discourse is the reality created by the means of mass information, which produce, store and spread socially important information. Accordingly, media text is the dynamic complex unit of the highest order with the help of which the information transmission occurs. The notion "media text" serves as a hyperonym to the entire range of terms: journalistic text, PR-text, publicistic text, newspaper text, radio text, TV-text and so on (Solganyk, 2015).

To its main categories belong media character, mass character, integrity or polycoding, openness and intertextuality:

- Media character: media text is determined by the communication channel. Each method of mass information can be characterized by a set of media features, which exert influence on the text properties;

- Mass character: mass communication specification lies in the fact that it is sociallyoriented communication, where the figures of both author and recipient are subjected to changes;

- Integrity (polycoding): modern media texts according to the form of their creation and form of their representation are multimodal that is they are verbal, visual, audiovisual and other components which integrate in one sematic space;

- Openness: media text cannot be characterized by the sematic completion since it is the structure, which is open to multiple interpretations: mass media text is a phrasal unity of endless hypertexts with the great variety of references and quotations;

- Intertextuality: any media text is a part, fragment of the information continuum, which serves as a communicative background and provides sematic ambiguity of the message interpretation by the reader (Smetanina, 2002; Ticher, 2009).

The main functions of media discourse are:

- informative (transmission of information);

- regulatory (verification of knowledge, meanings, etc. in order to ensure that the process of information decoding will be effective);

- educational (replenishment of knowledge of the object of communication);

- entertaining (establishing of the favourable conditions for collaboration and interaction);

- the function of influence (ability to obtain a pre-planned result with the help of evaluative, expressive means, etc.);

- the function of socialization (integration of the addressee into the social system).

There are various typologies of media discourse. So far, the most complete and adequate classification has been proposed by Solhanyk. The classification takes into account the following 
parameters: method of creation (single vs. co-authored and multi-authored); media text form (verbal, nonverbal, creolized); distribution channel (printed, TV, radio or Internet media texts); functional-genre type of text (traditional journalistic texts, informational, analytical, literary and social-scientific, advertising and PR texts) (Cutting, 2002; Potapenko, 2000).

\subsection{Theoretical framework of the investigation of allusion and term phenomena}

As it was mentioned above the distinctive feature of modern media discourse is the extensive use of the combination of allusions and terms. This unique phenomenon is known as "terminological allusiveness". However, to investigate the essence of this phenomenon it is needed to give on outlook on both notions allusion and term and distinguish their main features.

Despite an enormous variety of definitions a significant theoretical prerequisite of the investigation of the allusion phenomenon is its examination from the point of view of intertextuality. According to Fateyeva allusion is a "borrowing of certain pretext elements, which are discerned in the recipient text, where their predication occurs". Allusion can also be considered from the standpoint of literary studies, cognitive science, linguostylistics, linguocultural studies, semantics and pragmatics. Very often allusion is considered as a stylistic device. Allusion can be characterized by the wide range of functions. Not only it evokes the visual and sensual images in the reader's imagination, but with its help author also expresses his attitude to events or situations by comparing two texts. As far as the typology of allusions is concerned, there are six main classifications based on different criteria. Allusions can be classified according to thematic, pragmatic, graphic and functional criteria as well as on the basis of their representation way and use of proper nouns (Tiutenko, 2000).

However, in modern media discourse two types of allusions are distinguished: explicit and implicit. Explicit allusions are available on the surface of the text. Those allusions are obvious due to their being well-known. For instance, "But you do realize, that when they find out about your plan, it will sink like the Titanic". In this example allusion is represented by the proper name Titanic, which reproduces an associative connection with the image of a submerged ship. No additional elements are needed to decode this allusion (Lavrynenko, 2006). A characteristic feature of implicit allusions is that they are veiled. Such allusions interlace with the text's tissue and actualize the content without violating the coherence of the text. Therefore, these units are difficult to decode and to do this the reader has to have a vast body of knowledge: "I don't know how to explain this, but every time he's not here, my heart misses him. I feel that I'm fond of him completely". In this example there is no direct connection with the allusion (Lennon, 2004).

As far as the notion "term" is concerned, it is such a multifaceted phenomenon that there are various approaches to its classification and subdivision into certain subclasses. Proponents of the traditional approach view the term as a special word with its unique characteristics, as the opposite of a common word. Functional approach perceives it as a normal word with a special function. However, the most usual approach to interpreting this concept is a cognitive approach, which describes the term as a linguistic representation of knowledge and experience, a mental category, and as an important component of the professional communication (Selivanova, 2006).

Looking at the term as an ideal linguistic unit, it must necessarily be characterized by the following features: informativeness, normativity, systematicity, definiteness, and independence of context, unambiguous lack of synonymy, expressive neutrality, precision, brevity, affectionateness and proficiency. With regard to functional characteristics, the term calls a special concept and expresses its distinctive features, conveys special meaningful information, helps to perceive reality through processes, transmits feelings, opens new knowledge and compresses them (Dudok, 2006).

Most often terms are classified by fields of knowledge such as mathematical (logarithm), physical (aerodynamics), IT (system software), chemical (carbon), biological (autotroph), and geographical (map key). When the structure is considered, terms can be simple (circuit), derivative (fertilizer), compound (flywheel) and complex (circuit breaker). Quite often there are phrases (metal-oxide semiconductor field effect transistor), abbreviations (alternating current (AC) or signs (\%). Due to the desire to make scientific works available to the average readers, the colloquial 
variants of some verbs appear such as alopecia $\rightarrow$ baldness, dipsosis $\rightarrow$ thirst, hypertrophy $\rightarrow$ overgrowth, but still, most terms have no equivalents in common vocabulary (Danylenko, 1980).

The term is an integral part of the system, that fact determines its systematic nature. Terminology is a disordered set of terms of a particular field of knowledge. However, the term system is the organized terminology (Matviienko, 2003).

\subsection{Terminological allusiveness as an object of linguistic studies}

Terminological allusiveness is comparatively recent notion in linguistics as its profound examination started only in the beginning of the XIX century. It was first used to refer to the unusual combination of the allusive unit with the term in one sentence. Such a rare phenomenon has immediately generated an enhanced interest and comprehensive studies were launched, which were aimed to investigate the unique nature of this phenomenon. It took several years for the researchers to come up with the appropriate definition; however, there are still a great number of highly controversial issues regarding the essence of terminological allusiveness, its functions in the text and typology. The phenomenon of terminological allusiveness has given rise to long discussions, which do not swirl even nowadays.

Most often, terminological allusiveness is defined as a simultaneous borrowing from the pretext of the stylistic figure allusion and term, which form highly complex entity - allusion and terminology confluence - and, thus, provide intertextual connections within the recipient text. As a rule, this phenomenon is used in media text, where it performs several functions:

- Evaluative: allusive term transmits evaluative information, which creates characteristic for the event, phenomenon, person and so on;

- Text-structuring: allusive term provides the innertextual connection;

- Constructing: allusive term belongs to both micro- and macro-context;

- Representative: it names particular notions, categories, features, connections;

- Communicative: with its help allusive term fulfills the transmission of certain information and establishes inverse relationship with the reader;

- Pragmatic: it conveys the author's feelings and interconnects the language sign with the particular conditions, sphere and aim of communication;

- Epistemological: allusive term establishes connections of mental processes with the processes of reality investigation.

The phenomenon of "terminological allusiveness" possesses the following features:

- Referential nature: allusive term comprises either direct reference or implication to any scientific phenomenon;

- Implicitness: allusive term has indirect method of content expression and it gives rise to associations with diverse scientific terms and processes;

- Two-foldedness: allusive term possesses two main components - denotative and representative one;

- Consistency: it is a part of a certain terminological system;

- Contextual attachment: allusive term is dependent on the context;

- Expressiveness: in comparison to the ordinary term, it is characterized by the presence of the subjective and evaluative connotations (Diakov, 2000; Lavrynenko, 2009).

There are many various approaches to the typology of the notion "terminological allusiveness", which are based on diverse criteria. Overall, scientists distinguish seven key classifications of this phenomenon. They are listed below:

According to the various fields of knowledge:

Allusive terms of exact sciences:

1) Mathematical:

- Bakers Dozen is thirteen of something (or, more rarely, 14). The allusion to the former practice of bakers adding a thirteenth loaf of bread to a batch of twelve loaves in order to avoid punishment for accidentally selling underweight bread; 
- Gabriel's Horn is a geometric figure which has infinite surface area but finite volume. The name refers to the Christian tradition identifying the archangel Gabriel as the angel who blows the horn to announce Judgment Day.

2) Physical:

- Snap, Crackle, and Pop are sometimes used to describe the fourth, fifth and sixth time derivatives of position. This refers to the advertising mascots Snap, Crackle, and Pop which are used, though "sometimes somewhat facetiously";

- Doppler Effect is a change in frequency and wavelength of a wave. This refers to the Austrian physicist Christian Doppler, who described the phenomenon;

- Thor's Helmet is an emission nebula. This comes from its bubble shape and filaments resemblance to the depictions of the Norse god's helmet.

3) Computer science:

- Easter egg is an unexpected or undocumented feature in a piece of computer software or on a DVD, included as a joke or a bonus. The allusion to the tradition of the important Christian holiday;

- Bootstrapping is the program that initializes the operating system during startup. This comes from the phrase "to pull oneself up by one's bootstraps", originally used as a metaphor for any selfinitiating or self-sustaining process.

Allusive terms of natural sciences:

1) Chemical:

- Boyle's law is a law about ideal gases. The allusion to the chemist and physicist Robert Boyle, who published the original law;

- Grignard reaction is the addition of an organomagnesium halide (Grignard reagent) to a ketone or aldehyde, to form a tertiary or secondary alcohol, respectively. This refers to the French chemist François Auguste Victor Grignard who published it.

2) Biological:

- Sonic Hedgehog is a protein that in humans is encoded by the SHH gene. This comes from Sonic the Hedgehog, the protagonist character of the eponymous video game franchise;

- Alice in Wonderland syndrome (AIWS) is a rare condition of temporary episodes of distorted perception of body size. This refers to Lewis Carroll's famous novel Alice's Adventures in Wonderland;

- Venereal diseases are sexually transmitted diseases. This refers to Venus, the Roman goddess of love.

3) Geographical:

- Cappuccino cowboy is a person who combines a rural lifestyle with urban conveniences. This refers to the Starbucks and real cowboys;

- Cyclopean stairs is the landscape that results in a glacial trough after the ice has melted away. The allusion to the Cyclopes, the giants with one large round eye;

- Tropic of Capricorn is an imaginary line encircling the Earth at the latitude of 23 degrees 30 minutes south of the equator. This comes from the fact that when it was discovered the sun appeared directly overhead at this latitude during the winter solstice, it was entering the zodiac constellation sign of Capricorn.

According to the method of representation:

1) Simple:

- bug is a defect in mechanical systems. The allusion to Grace Hopper who traced an error in the Harvard Mark II to a moth trapped in a relay.

2) Compound:

- Eat your own dog food is the process when a computer company uses its own software for internal projects. This comes from the fact that if a dog food is of the high quality advertised to consumers, and then it should be good enough for a person to eat as well.

3) Direct: 
- Swing is graphics library for Java. This refers to the swing, a style of dance band jazz.

4) Indirect:

- Thunking is a function. This comes from a humorous past participle of "think".

According to the meaning:

1) Monosemantic:

- Tomcat is an open-source implementation. The allusion to the cartoon "Tom and Jerry".

2) Polysemantic:

- Gopher is a communications protocol. The source of the name is claimed to be two-fold: 1) gopher holes; 2) Goldy the Gopher, the mascot of the protocol authors' organization, the University of Minnesota.

According to the object of designation:

1) Objects, phenomena:

- Python is a programming language. The allusion to the television series Monty Python's Flying Circus.

2) Features and properties:

- Dwarf Planet is a small rocky body's that orbit the sun in our solar system. This comes from the folklore where dwarf is a small legendary manlike being who is usually misshapen and ugly and skilled as a craftsman.

3) Processes:

- Data mining is the knowledge discovery in databases. This refers to the actual mining, the process of digging things out of the ground.

4) Values:

- Joule is unit of energy. The allusion to the English physicist James Prescott Joule;

- Newton is unit of force. This refers to Sir Isaac Newton, whose second law of motion describes the changes that a force can produce in the motion of a body;

5) Symbols:

- «*» (asterisk) is a typographical symbol or glyph. This refers to the actual star.

6) Abbreviations:

- ID10T is user error. This is a thinly veiled reference to the CSR's opinion that the person reporting the problem is an idiot.

According to the type of motivation:

1) Fusion:

- Stars over Babylon is Thomae's function. The allusion to the Babylon, one of the most famous cities of antiquity.

2) Unity:

-Zombie process is a process whose execution is completed but it still has an entry in the process table. This comes from the zombie, reawakened corpse in religion.

3) Combination:

-WIMP (weakly interacting massive particle) are the hypothetical particles that are one of the proposed candidates for dark matter. This refers to the wimp, a weak, ineffectual, timid person.

According to the functioning:

1) General scientific:

- Yahoo! is an Internet portal. This term has an interdisciplinary nature. This refers to a person who is repulsive in appearance and action and is barely human from Jonathan Swift's book "Gulliver's Travels" and to yahoos (college students in the late 80's, the rude, unsophisticated, rural southerners as the founders Jerry Yang and David Filo.

2) Inter-branch:

- Avogadro's number is the number of particles (usually atoms or molecules) in one mole of a given substance. It is a chemical and physical term. The allusion to the Italian scientist Amedeo Avogadro.

3) Highly specialized: 
- Ugly duckling syndrome is a constant feeling of imperfection. It is used only as a psychological term. This refers to the story of The Ugly Duckling by Danish poet and author Hans Christian Andersen.

The following classes of proper names are distinguished by denotations:

1) Anthroponyms:

- Witch of Agnesi is a cubic plane curve defined from two diametrically opposite points of a circle. This comes from Italian mathematician Maria Gaetana Agnesi, and from a mistranslation of an Italian word for a sailing sheet.

2) Toponyms:

- Cummingtonite is the mineral. This refers to the town of Cummington, Massachusetts, where it was discovered.

3) Cosmonyms:

- Aurora Borealis are natural phenomena featuring beautifully colored light displays over the Earth. The allusion to the Roman goddess of dawn, Aurora and to the Roman god of the north wind, Boreas;

- Black Hole is a place in space where gravity pulls so much that even light can not get out. This refers to the phrase "like the Black Hole of Calcutta" (a small room used as a prison in Calcutta, India where many British prisoners died during one night in 1756).

4) Theonyms, mythonyms:

- Kerberos is a computer network authentication protocol. The allusion to Kerberos, in Greek mythology the three-headed dog guarding the gates of Hades;

- Trojan horse is any malware which misleads users of its true intent. The name refers to the classical myth of the Trojan Horse. Analogously, a Trojan horse appears innocuous, but in fact is a vehicle for bypassing security;

- Devil's curve is the term of geometry. This comes from the diabolo game. The confusion is the result of the Italian word "diabolo" meaning "devil";

- Doomsday argument is a mathematical formula. The name refers to the religious apocalyptic worldviews (Sager, Dungworth \& Mcdonald, 1980; Yarema, 2017).

Therefore, as can be seen from numerous examples, the concept of terminological allusiveness is becoming quite common in media discourse.

\section{CONCLUSIONS AND SCOPE FOR FURTHER RESEARCH}

The research shows that terminological allusiveness is one of the modern constituent of the media discourse. We have found out that the main value of media discourse is, on one hand, the concept of "information", or, to be more precise "satisfaction of the need in information". On the other hand, media discourse takes an active part in the implementation of the movement of social thought and the formation of an individual conceptual view of the world. Thus, the media discourse plays an important role in ensuring dynamic communication, maintaining social balance and at the same time, becoming an instrument of consciousness manipulation. That is why, the terminological allusiveness as a linguistic phenomenon tries to combine two principles - logical/conceptual and figurative, as along with its special meaning, it simultaneously performs a certain stylistic function. Therefore, the results of our research have proved that the terminological allusiveness is an interesting object for linguistic research and an important component of our modern life that deserves special attention.

\section{REFERENCES}

Cutting, J. (2002). Pragmatics and Discourse. London and New York. [in English]

Danylenko, V. P. (1980). Teoretychni ta praktychni aspekty normalizaciyi naukovoyi terminologiyi [Theoretical and practical aspects of normalization of scientific terminology]. Kyiv. [in Ukrainian]

Dudok, R. I. (2006). Termin ta jogo strukturno-semantychnyj potencial [Term and its structural and semantic potential]. Sumy. [in Ukrainian]

Diakov, A. S., Kyiak, T. R., \& Kudelko, Z. B. (2000). Osnovy terminotvorennya: semantychni ta sociolingvistychni 
aspekty [Basics of terminology: semantic and sociolinguistic aspects]. Kyiv. [in Ukrainian]

Lavrynenko, O. O. (2006). Alyuziya yak zasib konceptualnoyi reprezentaciyi znan [Allusion as a means of conceptual representation of knowledge]. Kyiv. [in Ukrainian]

Lavrynenko, O. O. (2009). Komunikatyvno-pragmatychnyj potencial alyuziyi v anglijskomu ta ukrayinskomu publicystychnomu dyskursi [Communicative and pragmatic potential of allusion in English and Ukrainian journalistic discourse]. Kyiv. [in Ukrainian]

Lennon, P. (2004). Allusions in the Press: Applied Linguistic Study. Mouton De Gruyter. [in English]

Matviienko, P. V. (2003). Ukrayinska interpretaciya anglomovnykh terminiv [Ukrainian interpretation of English terms]. Kyiv. [in Ukrainian]

Potapenko, S. I. (2000). Suchasnyj anglomovnyj media-dyskurs: lingvokognityvnyj i motyvacijnyj aspekty [Modern English-language media discourse: linguocognitive and motivational aspects]. Nizhyn. [in Ukrainian]

Sager, J. C., Dungworth, D., \& Mcdonald, P. F. (1980). English special languages. Principles and practice in science and technology. Wiesbaden. [in English]

Selivanova, O. O. (2006). Suchasna lingvistyka: terminologichna encyklopediya [Modern linguistics: a terminological encyclopedia]. Poltava. [in Ukrainian]

Smetanina, S. I. (2002). Mediatekst v systemi kultury` (dynamichni procesy v movi i styli zhurnalistyky kincya XXI stolittya) [Media text in the system of culture (dynamic processes in the language and journalism of the end of the XXI century]. Kharkiv. [in Ukrainian]

Solganyk, G. Ya. (2015). Stylistyka tekstu [Stylistics of a text]. Kyiv. [in Ukrainian]

Ticher, S., \& Mejer, M. (2009). Metody analizu tekstu i dyskursu [Methods for analyzing text and discourse]. Kharkiv. [in Ukrainian]

Tiutenko, A. A. (2000). Struktura i funkciyi alyuzij v presi [The structure and functions of allusions in the press]. Kharkiv. [in Ukrainian]

Yarema, O. B. (2017). Krosdyscyplinarnist yavyshha alyuziyi [Cross-discipline of the phenomenon of allusion]. Naukovyj visnyk Mizhnarodnogo gumanitarnogo universytetu [Scientific Bulletin of the International University for the Humanities], 31(2), 141-143. [in Ukrainian]

Ольга Демиденко, Людмила Власюк, Олена Мірошниченко. Термінологічна алюзійність як характерна риса сучасного медіа дискурсу. У сучасних умовах ЗМІ є невід'ємною частиною суспільного життя. Медіа дискурс це потужний інструмент впливу на людську свідомість. Мова 3МІ динамічна за своєю природою, а отже здатна швидко реагувати на всі зміни громадської думки. Саме в мові ЗМІ найяскравіше відображаються останні тенденції в підходах до дослідження мови. Особливе місце посідає «термінологічна алюзійність», яка відіграє важливу роль у вивченні мови XIX століття. Цю статтю присвячено дослідженню такого лінгвістичного явища, як термінологічна алюзійність, а саме їі функціонуванню в медіа дискурсі. Перш за все, в статті представлено загальний огляд головних ознак, функцій та категорій медіа дискурсу. Окрім того, чітко охарактеризовано ключові особливості таких лінгвістичних явищ, як алюзія та термін. Також, особливу увагу було приділено незвичному поєднанню алюзійних одиниць з термінами природничих та точних наук як особливій стилістичній фігурі, що застосовується в медіа дискурсі. В статті також надано різноманітні підходи до класифікації вищезгаданого лінгвістичного явища. Кожна класифікація проілюстрована численними прикладами. Це дослідження дає поштовх до подальшого дослідження явища термінологічної алюзійності. Результати цього дослідження стануть в нагоді досліднику-лінгвісту, який займається вивченням медіа дискурсу.

Ключові слова: алюзія; лінгвістичні дослідження; медіа дискурс; медійний текст; термінологічна алюзійність; термінологія природничих та точних наук; вихідне слово; похідне слово; семантична модель; еквівалент; перекладацькі трансформації. 